\title{
Pros and Cons of Women Empowerment
}

\section{OPEN ACCESS}

Volume: 7

Issue: 4

Month: September

Year: 2019

P-ISSN: 2320-2653

E-ISSN: 2582-1334

Received: 21.06.2019

Accepted: 26.08.2019

Published: 01.09.2019

Citation:

Siddaraju, KS. "Pros and Cons of Women Empowerment." Shanlax International Journal of Education, vol. 7, no. 4, 2019, pp. 38-41.

DOI:

https://doi.org/10.34293/ education.v7i4.566

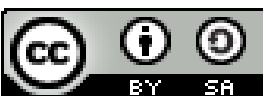

This work is licensed under a Creative Commons Attribution-ShareAlike 4.0 International License

\author{
K.S.Siddaraju \\ Lecturer in Education, JSS Institute of Education, Chamarajanagar, Karnataka, India
}

\begin{abstract}
The empowerment of women is one of the focusing issues in the process of developing countries over all the world. The International Women's Day celebrated on 8th March each year has become a day of demonstration for equal opportunity and solidarity. But the question arises how relevant is a celebration of Women's Day because their position in the society has not changed much. They are still treated as the 'weaker section of the society'.
\end{abstract}

Keywords: Solidarity, weaker sections of the society, assertion, self-esteem, self reliance, legal machinery, Elites.

\section{Introduction}

Women establish about half of the total population of the country, but they suffer from many disadvantages as related to men in terms of literacy rates, labour participation rates earnings. Social, economic and political empowerment is the need of the day, as it is one only surest way of making women empowerment it is conceptualised in terms of personal assertions, self-esteem and confidence, ability to protect themselves as women obtain socio-political participation and economic independence, ownership of productive assets and provide leadership in women.

Government of India prepared a National document which lays down various strategies for women's development and declared the year 2001 as "year of women empowerment" 1993 was an effort to grant some special powers to women in all the three tiers of Panchayat Raj System. 1/3 of seats are quiet for women in addition to SCs and STs. This has created awareness among the women but failed to bring drastic change as per expectations. It suffers from some serious drawbacks such as illiteracy, lack of knowledge, non-availability of able women, corrupt leadership and Bias towards Elites and middle class. Even though the political parties speak now and then in elections $33 \%$ of reservations for women candidates in Legislative and parliament elections.

Some of the empowerment mechanisms in India could be described as follows:

1. Literacy and higher education;

2. Better health care for herself and her children;

3. More upper age at marriage; Greater work participation in the modernized sector;

4. Necessary financial and service support for self-employment;

5. achieve knowledge for her rights;

6. Self-reliance, self-respect and dignity of being a woman.

The Constitution of India made a consider a radical departure from the inherited social system. By granting women equal social and political status. Constitutional same status meant that every adult female, whatever her social position or accomplishments, had the opportunity to function as a citizen and specific partner in the task of nation-building. 
With the exception of cultural empowerment of women, the following aspects of women empowerment are given importance such as full participation of women in democracy (political empowerment); the education of girls (social empowerment) the eradication of gender barriers in employment (economic empowerment); and land rights and legal machinery (legal empowerment).

Besides the 33 per cent reservation of seats for women in the Panchayati Raja institutions is undoubtedly a revolutionary step toward the empowerment of rural women. The Seventy-third and Seventy-fourth Constitutional provisions paved the way for the emergence of about one million women as leaders and decision-makers in the country and urban elected bodies. This will empower' women politically at the grass-roots level in a revolutionary fashion, and it will enable them to take an interest at the local level to energise and improve the situation of women in areas like health, education and employment, which essential to their necessary existence.

Against their vast numerical strength, women occupy a marginalized position in society because of several socio-economic constraints, This has inhibited the active participation of women in political equality, statistics have over the years revealed that while there is a respectable visible demonstration of gender quality at the voter level, gender clarity within the power structures show cause for women concern. According to the evidence on Women's Development (1985), women's role in the political formation had remained constant, despite the rapid growth of informal political activity by them.

\section{Constitutional Provisions towards Empowerment of Women}

Article 15(3) of the Indian structure empowers the state from making any special provisions for women and children. Art 31 (d) directs that rule shall in practical directs its policy towards securing equal pay for equal work for both men and women.

Art 42 makes provision for securing just and human conditions of work and for maternity relief.

Child Marriage Restraint Act 1929 to was passed to prevent child marriage. In 1856 the Hindu Widow's Marriage Act was given some other legislation regarding women in matters of marriage, adoption and inheritance are:

1. In December 1829 Sati was declared illegal and abolished.

2. Hindu law of legacy amendment Act 1929.

3. The Hindu women Right to Property Act 1937.

4. The unique marriage act 1954 , which provides rights to women on par With men for intercaste marriage, love marriage and registered a marriage with a minimum age of marriage at 18 for females and 21 for males.

5. Hindu marriage Act 1955, which ban polygamy, polyandry, and child marriage and allow equal rights to women to divorce and remarry.

6. Hindu Succession Act 1956 which provides for women the right to parental property.

7. Hindu Adoption and Maintenance Act 1956, which gives childless women the right to adopt a child and to believe maintenance from the husband if he divorces her.

8. Hindu Dowry Prohibition Act 1961, declares the practice of illegal dowry Activity and thereby prevents the exploitation of women.

9. The suppression of corrupt Traffic of Women and Girls Act 1956 provides Protection to women from being kidnapped and being compelled to become prostitutes.

10. The Medical Termination of Pregnancy Act 1971, which legalise the abortion accept the right of a woman to go for abortion on the ground of physical and mental health.

11. The criminal law amendment act 1983 aims to stop various types of crimes against women.

12. The Family Court Act of 1984 provides justice to women who get involved in family disputes.

13. The Indecent depiction of Women (Prohibition) Act 1986 prohibits the vulgar presentation of women in the media such as newspapers, cinema, $\mathrm{TV}$, etc.

\section{Women and the Work Place}

Educated women are one of the main engines of the dynamic economy of India because they are pouring into the professional workforce with a profound implication of national and multinational corporations. 
1. Harassment of women at the workplace is the most unwanted development. Woman are economically exploited threat of removal is always there a woman employees. Women are given more work and less pay. Discrimination is also made in providing opportunities of a new appointment, promotion, increment, training, allowance, etc., sexual harassment of women at workplace is always on increasing trend without any precise control over it Amnesty International has observed that Indian women are regularly raped in jail cells. Even, the United Nations has pointed out that India has the highest number of custodial rapes by men is a position of power.

2. As highly qualified women in emerging markets struggle to balance the depends of career, children and culture employers have an unprecedented opportunity to help them fully realize their potential, to do so the competencies or the employers will have to gain a deeper understanding of ambitions and needs of their top female talents and alter their policies accordingly. But the lessons learned in attracting, assist and retaining the best and brightest women can only enhance and strengthen an organisation's operations worldwide. Helping these talented women grow is the surest route to continued growth now and in future.

3. In India position of Hindu women is better than that of Muslims wherein (Talak) Divorce, Mohar, Remarriage is allowed on the other hand women of Christians and Parsees enjoy better position than that of Hindu because of Higher Education and Employment.

4. At present, we see the establishment of separate schools and colleges for women. In 1958-59 there were 146 colleges for women, it was increased to 824 colleges in 1992, and now it has crossed 1000 mark.

\section{Establishment of Separate Women Universities}

Article 29(2) permits the state and private citizens to establish educational institutions only for women colleges and universities. Examples are:

1. Smt. Nathibai Damodar Thackersey University for Women, Poona

2. Padmavati University for Women, Tirupathi, Andhra Pradesh
3. Mother Teresa University for Women, Kodaikanal, Tamilnadu

4. Women's University, Bijapur, Karnataka, etc.

Girl students are getting admissions on merit basis to various courses of prestigious engineering, medical, administration law and other colleges in relatively more significant number during the recent years. Women have now realised the importance of higher education.E ven the parents are encouraging their daughters to get higher education. Still, $60 \%$ of our rural women are illiterate, and only a few of them develop their educational career through their intelligence and reasonable efforts.

\section{Conclusion}

Thus road map for women empowerment is there, but still, we have miles to go on this path of empowerment.

It has been rightly said by Swami Vivekanand. "The Best thermometer to the proceed of a nation is its treatment of women". Therefore, due recognition to them in society and their greater involvement in socio-economic and political affairs becomes all the more important. Every person should come forward to ensure equal status for women in all spheres of life.

The Empowerment of women has become one of the essential concerns of the 21 st century, not only at a national level but also at the international level. Efforts by the Government are on to ensure Gender equality, but Government initiatives alone would not be sufficient to achieve this goal. Society must take action to create a climate in which there is no gender discrimination and Women have full opportunities of self-decision making and participating in the Social, Political and Economic life of the Country with a sense of equality.

While the welfare approach laid stress on the importance of women as wives, mothers and careers of family welfare, the anti-poverty strategy was built on two strategies-need for recognising women's participation to family income paid and unpaid works. There was full effort to mobilise the power of women and give them economic support through income-generating projects and cooperative functioning. This approach aims to ensure women's rightful and equal position in society through direct 
programmes that would enhance women's activities in both the household as well as market spheres. Thus began the strategy for the empowerment of women in India.

\section{References}

Anupama Devi B. A Study on Teaching Attitude and Aptitude of B.Ed. Trainees in relation to Intelligence, Personality about SocioDemographic variables. Diss. S.V. University, Tirupathi, 2014.

Bonner, J. "Implications of Cognitive Theory for Instructional Design." Educational Communication and Technology, vol. 36, no. 1, 1988, pp. 3-14.

Chaudary, I. and Nosheen, F. "The Determinants of women Empowerment in Southern Punjab, Pakistan: An Empirical Analysis." European Journal of Social Sciences, vol. 10, no. 2, 2009, pp. 216-229.

Eisner, E. "The Satisfactions of Teaching." Educational Leadership, vol. 63, no. 6, 2006, pp. 44-46.

Godalaksmi, K. Evaluation of Pre-school, in
Tirupati, Diss. S.V. University, Tirupati, 1991.

Kabeer, N. "Reflections on the Measurement of Women's Empowerment." Discussing Women's Empowerment - Theory and Practice, Side Studies No. 3, 2001, pp. 17-57.

Kakkar S.B. "Values Scores of Teacher Trainees and College Teachers." Indian Journal of Applied Psychology, vol. 8, 1971, pp. 77-80.

Mukherjee, R. Rural Women Empowerment, Adhyayan Publishers and Distributors, New Delhi, 2008.

Ministry of Human Resource Development, National Policy on Education (1986), New Delhi.

Rathod P.B. Women and Development. ABD Publishers, 2009.

Saksena, K. Women and Politics. Gyan Publishing House, 2000.

SCERT. Play Materials for Children in Tamilnadu - A Manual for Teachers Chennai, State Institute of Education, 1991.

Subramanyam Naidu N. A study of attitude and aptitude of secondary school teacher towards the teaching profession, Diss. 2012.

\section{Author Details}

K.S.Siddaraju, Lecturer in Education, JSS Institute of Education, Chamarajanagar, Karnataka, India. 